\title{
TRADE AND LABOUR STANDARDS - THEORY, NEW EMPIRICAL EVIDENCE, AND POLICY IMPLICATIONS
}

\author{
VIVEK H. DEHEJIA \\ YIAGADEESEN SAMY
}

CESIFO WORKING PAPER NO. 830

CATEGORY 7: TRAde Policy

DECEMBER 2002

\begin{abstract}
PRESENTEd at CESifo CONFERENCE ON Globalization, INEQUALITY AND WELL-BEING, NOVEMBER 2002
\end{abstract}

\footnotetext{
An electronic version of the paper may be downloaded

- from the SSRN website:

www.SSRN.com

- from the CESifo website: www.CESifo.de
} 


\title{
TRADE AND LABOUR STANDARDS - THEORY, NEW EMPIRICAL EVIDENCE, AND POLICY IMPLICATIONS
}

\begin{abstract}
Recent trade negotiations, both at the regional and multilateral level, have seen a resurgence of the issue of trade and labour standards. As the world economy becomes increasingly globalised and the volume of world trade flows keeps increasing between the North and the South, it is very likely that the interaction of labour standards and international trade will continue to remain high on the agenda of future trade talks. Labour interests in highstandards countries argue that low labour standards are an unfair source of comparative advantage, and that increasing imports from low-standards countries will have an adverse impact on wages and working conditions in high-standards countries, thus leading to a race to the bottom of standards. For low-standards countries, there is the fear that this is just a form of disguised protectionism and that the imposition of high labour standards upon them is equally unfair since it will erode their competitiveness, the latter being largely based on labour costs. Our objective in the present paper is to cast some light on the above debate from both a theoretical and empirical perspective. In particular, we first discuss some possible theoretical links between labour standards and comparative advantage through their effects on the terms of trade. We then investigate empirically the effects of labour standards on export performance and foreign direct investment flows. Overall, our empirical results suggest that caution should be exercised before drawing broad conclusions on the magnitude and direction of these effects. We conclude by presenting policy implications of our analysis.
\end{abstract}

JEL Classification: F1, J8.

Vivek H. Dehejia

Department of Economics

Carleton University

1125 Colonel By Drive

Ottawa ON K1S $5 B 6$

Canada

vivek_dehejia@carleton.ca

\author{
Yiagadeesen Samy \\ Department of Economics \\ University of Ottawa \\ 550 Cumberland \\ Ottawa, ON K1N 6 N5 \\ Canada
}

The original version of this paper was presented at the CESifo conference on "Globalisation, Inequality and Well-being", Munich, Germany, 8/9 November 2002. This revision has benefitted from the helpful comments of the discussant, Alessandro Cigno, as well as conference participants, notably, Hans-Werner Sinn. The responsibility for errors and omissions is ours. 


\section{Trade and Labour Standards: Theory, New Empirical Evidence, and Policy Implications}

\section{$1 \quad$ Introduction}

The issue of trade and labour standards has been at the forefront of both regional and multilateral trade negotiations over the past two decades, and will likely remain high on the agenda of future trade talks as North-South trade flows continue to increase. When the North American Free Trade Agreement (NAFTA) was being negotiated in the 1990s, concerns were raised that low labour standards in Mexico could pose a threat to U.S. firms, leaving the latter at a comparative disadvantage and forcing them to close down or relocate production. Both the United States and France have also attempted (without much success) to introduce the issue of labour standards during the Uruguay Round; the United States has gone a step further by including a worker rights clause into many of its trade agreements, thus denying special trading benefits to countries who fail to comply with the U.S. definition of workers' rights.

Labour standards can be defined as a set of worker rights provided and enforced by national governments of different countries, the levels of which are both a reflection of these countries' preferences and the extent to which they comply with international conventions (from the International Labour Organization, henceforth ILO) which they have signed. The level of labour standards chosen by a particular country is ultimately a function of that country's level of economic development, and is therefore a domestic policy choice (Alam, 1992), which means that one should expect diversity in labour standards as the norm. The argument from trade theorists, who believe that gains from trade stem from diversity instead of uniformity, is that improvements in labour standards 
can be brought about with free and unrestricted trade, which tends to lead to higher rates of growth, or by creating a greater consensus on a set of international labour standards which all countries should abide by.

The reason why this issue of trade and labour standards is so much debated in trade negotiations and policy discussions is essentially as follows. Labour interests in high-standards countries argue that low labour standards are an unfair source of comparative advantage, and that increasing imports from low-standards countries will have an adverse impact on wages and working conditions in high-standards countries, thus leading to a race to the bottom of standards. For low-standards countries, there is the fear that the imposition of high labour standards upon them is just a form of disguised protectionism and is equally unfair since it will erode their competitiveness, which is largely based on labour costs. The present paper is a contribution to the above debate from both a theoretical and an empirical perspective.

Theoretically, it establishes the conditions under which and the reasons why countries might opt for a given level of labour standards that go beyond just the concern for human rights. At the empirical level, the paper investigates the effects of labour standards on export performance and foreign direct investment (FDI) flows. If the popular views on the issue of trade and labour standards are correct, one should expect low-standards countries to enjoy a better export performance and attract more FDI than high-standards countries, ceteris paribus. We present both time series and cross sectional estimates, and our empirical results imply that the choice of proper indicators for labour standards is extremely important in order to carry out any meaningful empirical exercise. They also suggest that caution should be exercised before drawing broad conclusions on 
the magnitude and direction of labour standards on export performance and FDI flows. This paper, therefore, reports on research that is part of an ongoing research project of the authors.

The paper proceeds as follows. Section 2 establishes some theoretical links between labour standards and comparative advantage through their effects on the terms of trade. In sections 3 and 4, we present some new empirical evidence regarding the effects of labour standards on export performance and FDI flows, using both cross-sectional and time series data. Section 5 concludes with some policy implications of our analysis.

\section{$2 \quad$ Theory}

Theoretical work linking international trade with labour standards is relatively scarce. The classic early studies, for instance by Johnson (1969) and Brecher (1974a and 1974b), considered minimum wages and their welfare implications but did not consider other internationally accepted labour standards such as the number of hours worked, the freedom from forced labour or unionization. On the other hand, Alam (1992), in an unpublished doctoral dissertation, was one of the first to provide a more general framework for the economic analysis of the impact of labour standards, at constant goods prices, on a country's comparative advantage within the framework of a two-country, twocommodity, two-factor model. Brown et al. (1996) focused on the welfare and other effects of standards and whether it is in a country's interest to implement common international standards. They use general equilibrium analysis by considering different variants of the standard two-good two-factor Heckscher-Ohlin-Samuelson model in order to analyse the effects of standards on the terms of trade. The different models in Brown et al. show that the effects of labour standards are dependent on the technology of 
production of goods and standards, and also on whether the standards are endogenous. Some of these results are anticipated as well in unpublished work by Dehejia and Garbo (1994).

We should mention as well that, while the mechanism through which we model the standard is the usual way it is done in the trade-theoretic literature, there are other alternatives. For instance, Sinn (2003), in his forthcoming Jahnsson lectures, builds a dynamic model in which the standard directly raises labour costs and is perceived as a non-pecuniary "wage" by workers, and uses this to demonstrate a natural tendency towards convergence between high- and low-standard countries as the latter catch up with the former through capital accumulation and growth.

\subsection{The Model and Results}

We use a standard Heckscher-Ohlin trade model to examine the effects of imposing labour standards in a country. Two countries ( $I$ and $I I)$ produce two traded goods $(X$ and $Y)$ and each good uses two factors of production, labour $(L)$ and capital $(K)$. Perfect competition is assumed to prevail in commodity markets and in factor markets. Technology and preferences are identical in both countries and are assumed to be CobbDouglas in this model. Labour and capital are available in fixed amounts in each country; each factor of production is perfectly mobile within the country but cannot be sent abroad. The two countries engage in trade and goods can be exported or imported at zero transport costs. As a result, differences in relative overall endowments drive comparative advantage in such a model. 
In equilibrium, the terms of trade $p\left(=p_{y} / p_{x}\right)$ must be such as to clear the market for each good. In other words, world production must be equal to world consumption or the value of exports of a country must be equal to the value of its imports. By Walras's law, clearance of the market for good $X$ implies clearance of the other and we are thus able to write down the following equation for the terms of trade:

$$
p=\frac{Q_{x}^{I}-C_{x}^{I}}{Q_{y}^{I I}-C_{y}^{I I}}
$$

where $C$ 's denote the consumption of goods $X$ and $Y, Q$ 's refer to production levels and the superscripts refer to countries $I$ and $I I$. As mentioned above, technology is taken to be Cobb-Douglas, so that production of goods $X$ and $Y$ in countries $I$ and $I I$ respectively can be represented as follows:

$$
\begin{aligned}
& Q_{x}=K_{x}^{\theta} L_{x}^{1-\theta} \\
& Q_{y}=K_{y}^{\mu} L_{y}^{1-\mu}
\end{aligned}
$$

Consumption levels for goods $X$ and $Y$ are obtained by maximizing a Cobb-Douglas community utility function subject to a budget constraint. This results in the following expressions for consumption of goods $X$ and $Y$ in countries $I$ and $I I$ respectively:

$$
\begin{aligned}
& C_{x}^{I}=\frac{\alpha I^{I}}{p_{x}}=\frac{\alpha\left(w L^{I}+r K^{I}\right)}{p_{x}} \\
& C_{y}^{I I}=\frac{\beta I^{I I}}{p_{y}}=\frac{\beta\left(w L^{I I}+r K^{I I}\right)}{p_{y}}
\end{aligned}
$$

where $w$ and $r$ are the wage rate and rental rate respectively and where superscripts refer to countries. $\alpha$ and $\beta$ are the preference parameters associated with the community utility 
function and $\alpha+\beta=1$ and $0<\alpha, \beta<1$. Substituting equations (2)-(5) in equation (1) yields the following expression for the terms of trade:

$p=\frac{\theta^{\theta}(1-\theta)^{1-\theta}}{\mu^{\mu}(1-\mu)^{1-\mu}}\left[\frac{(1-C) K^{I}+(1-D) K^{I I}}{C L^{I}+D L^{I I}}\right]^{\theta-\mu}$

, and where $C=\mu+\alpha \theta-\alpha \mu$ and $D=\theta+\beta \mu-\beta \theta$. Since $\alpha+\beta=1$, then $C=D$, which means that equation (6) can be further simplified to

$$
p=\frac{\theta^{\theta}(1-\theta)^{1-\theta}}{\mu^{\mu}(1-\mu)^{1-\mu}}\left[\frac{(1-C)\left(K^{I}+K^{I I}\right)}{C\left(L^{I}+L^{I I}\right)}\right]^{\theta-\mu}
$$

Equation (6a) implies that one can express the terms of trade in terms of overall endowments, and technological and preference parameters.

\section{Terms of Trade with a Labour Standard}

We now want to look at the impact on the terms of trade of imposing a labour standard in one of the two countries. In a small country case, the change in trade due to the imposition of a labour standard would likely have no effect on world prices. In the present case, we assume that countries $I$ and $I I$ are sufficiently large to influence their terms of trade and we consider two different ways in which the labour standard might alter the terms of trade.

\section{Case 1:}

Suppose the labour standard is imposed in country $I$ only, and withdraws resources (both capital and labour) from one of the tradeable sectors (for instance sector $X$ ). We do not explicitly model how the labour standard will be produced but only assume that its effect is to lead to a reduction in output in the sector where it is imposed by using some amount 
of capital and labour. As a result of the labour standard being imposed, a smaller amount of good $X$ will be produced such that

$Q_{x}=(1-A) K_{x}^{\theta} L_{x}^{1-\theta}$ and $0<A<1$.

The terms of trade will then be equal to

$$
p=\frac{(1-A) Q_{x}^{I}-C_{x}^{I}}{Q_{y}^{I I}-C_{y}^{I I}}
$$

Substituting equation (7) and equations (3)-(5) in equation (8) and simplifying yields the following expression for the terms of trade:

$$
p=\frac{\theta^{\theta}(1-\theta)^{1-\theta}}{\mu^{\mu}(1-\mu)^{1-\mu}}\left[\frac{(1-C) K^{I}+(1-D) K^{I I}}{C L^{I}+D L^{I I}}\right]^{\theta-\mu}(1-A)
$$

Equation (9) is in fact equation (6) multiplied by (1-A), and it implies that the terms of trade fall when the labour standard is imposed in sector $X$, which is the export industry (since $d p / d A<0$ ). One should note, however, that the preference parameters associated with the community utility function will likely be of different magnitudes in the presence of the labour standard since the consumer will also derive utility from the labour standard in addition to the traded goods. On the other hand, if the labour standard is imposed in sector $Y$, and because world production is always equal to world consumption for each good, I can re-write equation (1) in terms of good $Y$ for country $I$ and good $X$ for country II. In this case, the terms of trade will be equal to

$$
p=\frac{\theta^{\theta}(1-\theta)^{1-\theta}}{\mu^{\mu}(1-\mu)^{1-\mu}}\left[\frac{(1-C) K^{I}+(1-D) K^{I I}}{C L^{I}+D L^{I I}}\right]^{\theta-\mu} \frac{1}{(1-A)}
$$

Equation (10) is equation (6) divided by (1-A) and it implies that the country will now experience an improvement in its terms of trade when the labour standard is imposed in 
the import sector. To summarize, therefore, a labour standard, modelled as above, will lead to an improvement or deterioration in the terms of trade depending on whether it is imposed in the import or export sector.

\section{Case 2:}

Suppose now that the same amount of tradeable goods $(X$ and $Y)$ is produced as in the case where there was no standard but that a fraction $(A)$ of output $X$ is then used to finance the labour standard. In other words, only $(1-A)$ of output $X$ is available for trade ${ }^{1}$. The fact that the labour standard is using some of the output of $X$ implicitly implies that it is once again using some amount of capital and some amount of labour. This gives rise to the following expression for the terms of trade:

$p=\frac{\theta^{\theta}(1-\theta)^{1-\theta}}{\mu^{\mu}(1-\mu)^{1-\mu}} \phi^{\theta-\mu}$

where

$\phi=\frac{(1-C)\left(K^{I}\right)+(1-D)\left(K^{I I}\right)+(\mu-1) A K^{I}}{C\left(L^{I}\right)+D\left(L^{I I}\right)-\mu A L^{I}}$

and where $C=\mu+\alpha \theta-\alpha \mu$ and $D=\theta+\beta \mu-\beta \theta$. The wage/rental ratio and the factor intensities for goods $X$ and $Y$ are also all dependent on the terms of trade, which is now dependent on $A$. Hence, once the value of $A$ is determined, and given overall endowments in both countries as well as technological and preference parameters, the terms of trade, the wage-rental ratio and the capital-labour ratios of goods $X$ and $Y$ are all determined in this model. A change in $A$ will therefore have an impact on the terms of trade, factor

\footnotetext{
${ }^{1}$ This is equivalent to saying that the labor standard uses the same technology as sector $X$. Even though this assumption is restrictive, it allows one to focus on the terms of trade effect. Introducing a different capital/labor ratio for the standard would add one more dimension to the model and bring one closer to a Komiya-type model where the tradeables and non-traded good have different capital intensities. Dehejia
} 
prices and factor intensities. Differentiating equation (14) with respect to $A$, the following expression is obtained:

$$
\frac{d p}{d A}=\frac{\theta^{\theta}(1-\theta)^{1-\theta}}{\mu^{\mu}(1-\mu)^{1-\mu}}(\theta-\mu) \phi^{\theta-\mu-1}\left[\frac{(\mu-1) K^{I}+\mu L^{I} \phi}{C L^{I}+D L^{I I}-\mu A L^{I}}\right]
$$

If we assume that incomplete specialization obtains, then $k_{y}>k^{I}$, that is, the capital-labour ratio of good $Y$ is greater than that of the economy, making the element in square brackets positive. The sign of equation (12) will thus depend on $(\theta-\mu)$, which is the difference between the capital-labour ratios of goods $X$ and $Y$. Hence movement of the terms of trade due to a change in $A$ depends on the capital-labour intensity of the tradeables. For example, if good $X$ was the capital-intensive good and country $I$ was capital abundant such that good $X$ was being exported, then $\theta>\mu$ which means that $d p / d A$ $>0$, and there would thus be a terms of trade gain when the labour standard is imposed in the export sector.

Even though we have only considered models where the labour standard is imposed by one country at a time in order to identify the terms of trade effects, it is quite possible that countries which trade with one another will each set their domestic labour standards at a certain level. For example, one could again use equation (1) to consider the effects of a labour standard in sector $X$ of country $I$ and sector $Y$ of country $I I$ and it is easy to see that the effects will not only depend on which sector the standard is imposed but also on the relative levels of the standard in each country. An important implication of the results obtained above is that countries will tend to impose labour standards in order to sway the terms of trade in their favour. For instance, a country might choose to set a 
labour standard in the import sector and thus obtain terms of trade gains; or alternatively, it could try to force its trading partner to adopt a labour standard in the latter's export sector, which would lead to a deterioration in its trading partner's terms of trade and hence improve its own.

The other implication of the above analysis is that countries will also have an incentive to set labour standards that are too high or too low and just for terms of trade gains, and that the absence of coordination will not allow them to reach the world optimum $^{2}$. In other words, because of the potential terms of trade gains, countries acting rationally from an individual point of view will not maximize global welfare. The results obtained thus far have shown that the imposition of a standard reduces production, the volume of trade and can also lead to an improvement or deterioration in the terms of trade. From the point of view of national welfare, the overall effect of standards will depend on the benefit that consumers derive from consuming the standard good and the loss in welfare due to reduced consumption of the traded goods, as well as the terms of trade effects of the standard on product and factor prices, which were considered in the previous section. Hence, even though standards may be distortionary, they may improve national welfare by providing benefits that are valued highly by consumers.

For example, suppose that there are $\mathrm{N}$ consumers indexed by $i=1, \ldots, \mathrm{N}$ in country I. In the absence of any labour standard, consumers will derive utility from the consumption of goods $X$ and $Y$. With a labour standard, each representative consumer has identical preferences and derives utility from

$$
U_{i}=x_{i}^{\alpha} y_{i}^{\beta} z_{i}^{\gamma}
$$


where $\alpha+\beta+\gamma=1$ and where $z$ represents the labour standard. This utility function implies that an individual's utility depends not only on the consumption of the two tradeables but also on the labour standard. Each individual possesses some amount of capital and some amount of labour such that individual $i$ 's income is given by $I_{i}=w L_{i}+$ $r K_{i}$, where $L_{i}\left(K_{i}\right)$ denotes labour (capital) owned by individual $i$. Also, $\sum_{i=1}^{N} L_{i}=L^{I}$ and $\sum_{i=1}^{N} K_{i}=K^{I}$, which are the overall endowments of labour and capital.

At the economy level, for country $I$, we can think of the labour standard as a non-traded good such that supply equals demand. It is assumed that the demand for the standard is proportional to national income, the factor of proportionality being equal to $\gamma$. Individual $i$ 's demand for the standard will correspondingly be equal to $\gamma I_{i}$. Preferences of individual $i$ can also be described by an indirect utility function $V_{i}=V_{i}\left(p, I_{i}\right)$, where $V_{i}$ represents the maximum utility obtained by individual $i$, given $p\left(=p_{y} / p_{x}\right.$, and taking $\operatorname{good} X$ as the numeraire) and $I_{i}$, as follows:

$V_{i}\left(p, I_{i}\right)=\frac{\alpha^{\alpha} \beta^{\beta} \gamma^{\gamma}\left(w L_{i}+r K_{i}\right)}{p^{\beta}}$

Suppose we assume that $L_{i}$ and $K_{i}$ are exogenous to individual $i$. Suppose also that the individual recognizes the effects of the labour standard on producer and factor prices. Based on these assumptions, we can substitute the expressions for $p, w$ and $r$ obtained previously while deriving the terms of trade, in $V_{i}\left(p, I_{i}\right)$ to obtain the following:

$V_{i}\left(p, I_{i}\right)=F\left(\phi^{D} L_{i}+\phi^{D-1} K_{i}\right)$

where,

\footnotetext{
${ }^{2}$ Brown et al also obtain this result in the case of a specialized economy. However, as Dehejia (1998) has pointed out, some of their results hinge on the assumption that the country fails to use an optimal tariff.
} 


$$
\begin{aligned}
& F=\alpha^{\alpha} \beta^{\beta} \gamma^{\gamma} \theta^{\theta}(1-\theta)^{1-\theta}\left[\frac{\mu^{\mu}(1-\mu)^{1-\mu}}{\theta^{\theta}(1-\theta)^{1-\theta}}\right]^{\beta} \\
& \phi=\frac{(1-C)\left(K^{I}\right)+(1-D)\left(K^{I I}\right)+(\mu-1) A K^{I}}{C\left(L^{I}\right)+D\left(L^{I I}\right)-\mu A L^{I}}
\end{aligned}
$$

Rewriting $i$ 's utility function in terms of the indirect utility function thus enables one to interpret the latter as $i$ 's welfare as a function of $A$ :

$$
W_{i}(A)=F\left(\varphi^{D} L_{i}+\phi^{D-1} K_{i}\right) \text { where } \phi=f(A)
$$

This welfare function is dependent upon the individual's income, the terms of trade and by construction the labour standard. Equation (16) tells us that as long as the marginal benefit from consuming the standard (represented by parameter $\gamma$ ) exceeds the possible welfare losses (either through reduced consumption of the tradeables or because of adverse changes in the terms of trade and their effects on factor prices), then there will be an incentive for the consumer to demand the labour standard. For the economy as a whole, the indirect utility function and the social welfare function will be respectively

$$
\begin{aligned}
& V\left(p, I_{I}\right)=\frac{\alpha^{\alpha} \beta^{\beta} \gamma^{\gamma}\left(w L_{I}+r K_{I}\right)}{p^{\beta}} \\
& W(A)=F\left(\phi^{D} L^{I}+\phi^{D-1} K^{I}\right)
\end{aligned}
$$

which are the same as equations (14) and (16) except that the individual factor endowments are replaced by the country factor endowments. Once again, national welfare will depend on the consumption of tradeable goods and the labour standard and as long as the sum of marginal benefits derived from consuming the standard is high enough, national welfare will be higher. 
Now that possible links between labour standards, comparative advantage and trade have been established, we empirically examine the issue of trade and labour standards in the next two sections of this paper by considering the effects of labour standards on foreign direct investment flows and export performance.

\section{New Empirical Evidence - Cross Sectional Analysis}

Using cross-sectional data and considering both developed and developing countries, we consider two questions related to the issue of trade and labour standards. First, whether the imposition of labour standards affects the export performance of countries; second, whether labour standards affect foreign direct investment (FDI) flows. We make use of several indicators for labour standards to answer these two important questions, namely the ratification of ILO conventions, the number of hours worked, the number of days of paid annual leave or the degree of unionisation.

Existing empirical work on the issue of trade and labour standards is also rather scarce. An OECD (1996) study tried to establish possible links between core labour standards, trade, foreign direct investment, economic development and employment. The actual effects of core labour standards (measured by freedom of association rights) on output were found to be negligible compared with other factors such as technological shifts, prices of raw materials and the terms of trade. As far as trade performance is concerned, the study found no evidence that countries with low labour standards achieved a better export performance than countries with high labour standards. Regarding FDI flows, a review of the evidence showed that core labour standards were not important determinants of investors' decisions. All the above results, according to the OECD, lead 
to the conclusion that the concerns of developing countries that core standards will adversely influence their international competitiveness is unfounded.

Mah (1997) analysed the relationship between core labour standards and the export performance of developing countries. More specifically, he considered the ratification of ILO conventions related to core labour standards for forty-five developing countries as an independent variable to analyse their export performance for 1993. Unlike the OECD (1996) study, which based itself on just plots, his regression results showed that ratification of the conventions related to freedom of association, collective bargaining, and non-discrimination lead to a deterioration of export performance. Similar results are obtained even when a capital cost element is added as an additional explanatory variable. Mah's results thus contradict the OECD findings that there is no relationship between export performance and the level of labour standards.

Rodrik (1996) used a variety of measures of labour standards (number of ILO conventions ratified, democracy index that represents civil and political rights, indicator for child labour, statutory hours of work in manufacturing, days of annual leave in manufacturing, and percentage of the labour force that is unionised) to analyse their effects on (i) labour costs (ii) comparative advantage and hence trade flows, and (iii) FDI. His results show that labour standards are significant determinants of labour costs when one controls for productivity; but they are not important determinants of comparative advantage, the latter being determined mostly by factor endowments. Regarding the effect of labour standards on FDI flows, by controlling for policy distortions, population and the growth rate, he finds that his indicators for democracy and child labour are significant and that low labour standards are in fact a deterrent for foreign investors. His 
results also indicate that ratification of conventions, both with regards to core labour standards and other labour standards, are not significant determinants of FDI.

\subsection{Data}

In order to estimate the relationship between 1) export performance and labour standards and 2) FDI and labour standards, cross-sectional macro-data are used for a sample of countries that consists of both developed and developing (OECD) countries. For the purposes of this paper, the sample of countries examined is taken from the OECD (1996) study and for which reliable data are available. ${ }^{3}$ The latest available data is gathered regarding indicators of labour standards, and these are explained below.

We obtain data concerning the ratification of core ILO conventions from ILOLEX, which is a database of international labour standards from the ILO. The total number of ILO conventions (tconv) ratified is obtained from the World Labour Report (1995), and it varies widely across countries. For instance, France, Italy and Spain have each ratified over one hundred conventions, whereas Korea and Botswana have ratified only four and two conventions respectively.

We consider an indicator of civil liberties obtained from Freedom House (1995), which is an annual survey of political rights and civil liberties and denote this variable as civilb. The checklist for civil liberties includes questions on the presence of trade unions, the effectiveness of collective bargaining, and freedom from exploitation by employers or union leaders. It is measured on a scale of 1 to 7 , with smaller values indicating more rights. Rodrik (1996) uses a formula that combines the civil liberties index and the political rights index to arrive at an index of labour standards. In fact, his "democracy" 
index is obtained from the following transformation: $(14-($ civilb + pright $)) / 12$, where pright stands for political rights. In the present paper, only the civil liberties index is used because it is our view that the political rights checklist includes questions that are related to human rights that go beyond just labour standards. ${ }^{4}$

We consider the normal weekly hours of work as per the labour regulations that are in effect in each country and denote this variable as hour. Some countries report the range of hours (for example, 44 to 48 per week according to industry) and in that case the minimum is chosen. The number of days of paid annual leave allowed in each country in accordance with domestic laws is also considered and this variable is denoted as leave. The number of days of annual leave normally increases with the number of years in service. To be consistent, the minimum is always picked.

We consider union membership as a percentage of the non-agricultural labour force for 1995. For some countries, due to a lack of data, trade union density for the years 1993 and 1994 are taken. We denote this variable as union. Finally, variable injuries, which indicates occupational injuries per thousand people employed, is considered. This variable can be interpreted as an indicator of safety at the workplace.

\subsection{Models Estimated and Empirical Results}

\subsubsection{Labour Standards and Export Performance}

The following model from Mah (1997) is used to assess the impact of ratifying core labour standards on the export performance:

\footnotetext{
${ }^{3}$ Please refer to the appendix for a list of countries examined and for data sources.

${ }^{4}$ This is a point also raised by Alessandro Cigno.
} 
$\log (\exp / g d p)_{i}=\alpha_{0}+\alpha_{1}$ labstd $_{i}+\varepsilon_{I}$

where,

$\exp$ is the export value in US dollars in 1995;

$g d p$ is gross domestic product in US dollars in 1995;

labstd is any one of the indicators for labour standards; and $\varepsilon$ is the disturbance term.

A second model from Mah (1997), which includes the capital cost effect on the export performance, is also considered:

$\log (\exp / g d p)_{i}=\beta_{0}+\beta_{1}$ rint $_{i}+\beta_{2}$ labstd $_{i}+\varepsilon_{i}$

where, rint is defined as the lending rate minus the rate of inflation and the other terms are as indicated above in equation (19). Equation (20) is just equation (19) augmented by the capital cost variable rint. Equations (19) and (20) are in fact an application of the perfect and imperfect substitutes model, which have been used to model the behaviour of exports and imports. The perfect substitutes model assumes that homogeneous goods such as wheat or sugar are traded on international markets at a common price, while the imperfect substitutes model is more suitable for differentiated products. In the perfect substitutes model, a country's export volume depends on domestic prices, money income, and factor costs within the country. The interaction of world demand and world supply in the perfect substitutes model determines a unique world price, which is equal to the import, export and domestic prices of traded goods (abstracting from transport costs and other trade barriers).

In the imperfect substitutes model, on the other hand, prices have to adjust in each time period to maintain the equality between demand and supply. Furthermore, there exist costs to changing prices in imperfect markets, and variable rint in equation (20) captures 
these additional costs of adjustment. ${ }^{5}$ Both equations (19) and (20) assume that the export performance of a country is determined by its price competitiveness. The effect of imposing a labour standard can therefore be viewed as an increase in the labour cost, which in turn results in a deterioration of the price competitiveness of a country.

In order to interpret the results obtained from estimating equations (19) and (20), the null hypothesis is that the coefficients $\left(\alpha_{1}\right.$ and $\left.\beta_{2}\right)$ of labstd ${ }_{i}$ are zero, hence implying that the export performance of the countries under study is not influenced by the ratification of labour standards. The alternative hypothesis in Mah's (1997) study is that ratification of labour standards erodes the price competitiveness of exports significantly such that the signs of the coefficients $\left(\alpha_{1}\right.$ and $\left.\beta_{2}\right)$ of labst $d_{i}$ are negative. Also, $\beta_{1}$ is expected to have a negative sign because an increase in the real interest rate can raise the capital cost and hence lead to a deterioration of price competitiveness. For the purposes of the present paper, it is assumed that the alternative hypothesis is that the signs of $\alpha_{1}$ and $\beta_{2}$ are different from zero such that a two-tail test is considered for the significance of the labour standard. Indeed, it is quite possible that some labour standards can improve the production process, stimulate workers, and hence enhance productivity. The OECD (1996) study, for example, considers this possibility. The overall effect on efficiency and export performance may therefore not be as clear as one would expect.

We first replicate Mah's empirical analysis but using 1995 data for exports and gross domestic product, and core ILO conventions ratified as of the end of 1995 as our labour standard. The year 1995 is chosen because this is the year for which the latest data are available for other indicators of labour standards, such as degree of unionization and

\footnotetext{
${ }^{5}$ The perfect and imperfect substitutes models are more explicitly presented in Goldstein and Khan (1985).
} 
total ILO conventions ratified. This allows us to test the robustness of Mah's results, especially when the conventions ratified are considered in isolation as carried out by Mah but also when they are included all at the same time in equations (19) and (20). We also check whether the choice of different (and more realistic) indicators for labour standards yields different conclusions. Whereas Mah's analysis focuses on core labour standards for developing countries only, we also consider all the conventions that have been ratified with respect to labour standards (denoted as variable tconv) and carry our analysis for developing countries and a broader sample that includes developed countries. The method of estimation for the various equations is ordinary least squares. Because we are dealing with cross-sectional data and a sample of heterogeneous countries, heteroskedasticity is a possibility and therefore White's test is applied to correct for it whenever necessary. The results are as follows.

In the case of developing countries (results not included), for both equations (19) and (20), when ILO core conventions are used as indicators for labour standards and are considered individually, only the conventions related to forced labour are not significant. This is indeed not a surprise since forced labour is quasi non-existent in most countries. There is strong evidence in support of the view that ratification of the other conventions has a negative effect on export performance. tconv, which goes beyond just core labour standards, is also significant for the sample of developing countries. Once developed countries are included in the sample of countries, the labour standards variables lose some of their significance. One possible explanation for this might be because richer countries tend to produce more capital-intensive goods such that labour is not as important a factor as in developing countries. 
When all the core ILO conventions ratified are included at the same time, they have a less significant effect on export performance (results not included). With regards to developing countries, the results for equation (19) show that only the conventions related to the right to organize and non-discrimination are significant. It is also not clear whether labour standards are more significant for developing countries than for developed countries as observed previously. The main conclusion that we can draw from this analysis is that Mah's results are not very robust to the specification used.

The next two tables show the results which are obtained when equations (19) and (20) are re-estimated using different indicators of labour standards other than conventions ratified. The variables that are considered are civilb, hour, leave, union and injuries, and, in effect, we are replacing labstd in equations (19) and (20) by the latter variables. It is our view that ILO Conventions ratified are not realistic indicators for labour standards since countries sign them while at the same time knowing that they are not binding. The index for civil liberties and the degree of unionization are obtained from actual surveys and as such are more realistic indicators of labour standards. Furthermore, hour and leave are guaranteed by domestic laws and are more likely to be enforced than the ratification of conventions from the ILO. 
Table 1: Estimated coefficients for equation (19)- Developing Countries

\begin{tabular}{|c|c|c|c|c|c|c|}
\hline $\begin{array}{l}\text { Explanatory } \\
\text { Variables }\end{array}$ & (1) & (2) & (3) & (4) & (5) & (6) \\
\hline Constant & $\begin{array}{l}4.84 * * \\
(2.12)\end{array}$ & $\begin{array}{c}4.60 \\
(2.01)\end{array}$ & $\begin{array}{l}5.82 * \\
(1.81)\end{array}$ & $\begin{array}{l}-0.33 \\
(0.93)\end{array}$ & $\begin{array}{c}-0.58 * * \\
(-3.43)\end{array}$ & $\begin{array}{l}-0.68 * * \\
(-2.32)\end{array}$ \\
\hline civilb & $\begin{array}{c}0.03 \\
(0.91)\end{array}$ & & & & & $\begin{array}{c}0.02 \\
(0.40)\end{array}$ \\
\hline $\log ($ hour $)$ & $\begin{array}{c}-1.30 * * \\
(-2.14)\end{array}$ & $\begin{array}{l}-1.21^{*} \\
(-2.00)\end{array}$ & $\begin{array}{l}-1.44^{*} \\
(-1.72)\end{array}$ & & & \\
\hline $\log ($ leave $)$ & $\begin{array}{l}-0.26 * * \\
(-2.61)\end{array}$ & $\begin{array}{l}-0.24 * * \\
(-2.50)\end{array}$ & $\begin{array}{c}-0.36 * * \\
(-2.79)\end{array}$ & $\begin{array}{c}-0.38 * * \\
(-2.84)\end{array}$ & & \\
\hline union & & & $\begin{array}{c}-0.01 \\
(-0.16)\end{array}$ & $\begin{array}{c}-0.01 \\
(-0.11)\end{array}$ & & \\
\hline injuries & & & & & $\begin{array}{c}-0.41 \\
(-0.69)\end{array}$ & $\begin{array}{c}-0.39 \\
(-0.63)\end{array}$ \\
\hline $\mathrm{R}^{2}$ & 0.29 & 0.28 & 0.33 & 0.25 & 0.28 & 0.28 \\
\hline $\mathrm{N}$ & 39 & 39 & 28 & 28 & 18 & 18 \\
\hline F-Stat (p-value) & $3.52(0.02)$ & $4.45(0.01)$ & $3.94(0.02)$ & $4.11(0.03)$ & $2.92(0.09)$ & $1.89(0.18)$ \\
\hline White Test (p-value) & $0.92(0.52)$ & $1.49(0.22)$ & $1.08(0.42)$ & $0.42(0.83)$ & $0.68(0.52)$ & $1.19(0.37)$ \\
\hline
\end{tabular}

Note: Except where indicated otherwise, the figures in parentheses are the t-values. ${ }^{*}\left({ }^{* *}\right)$ indicates $10(5)$ percent level of significance.

Columns (1) to (6) of Table 1 show some of the results when different combinations of labour standards are tried as explanatory variables. This procedure is a departure from Mah's (1997) methodology, which consists of introducing one indicator at a time to isolate the individual effects. It turns out that the significance of the variables in Tables 1 and 2 is not much altered when this change is implemented and that our results are therefore more robust to changes in specification. On the other hand, when the same 
procedure was applied to conventions ratified, the significance of the variables changed considerably.

As shown in Table 1 above, when equation (19) is estimated using these more realistic indicators for labour standards, the civil liberties index variable, the unionization variable and the variable related to occupational injuries are all insignificant. The coefficients for hours worked and paid annual leave are, however, both negative and significant. This shows that longer hours of work (more demanding working conditions) are associated with a deterioration of export performance, whereas better conditions of work (in terms of more paid annual leave granted) also lead to a deterioration of export performance. Hence, it is not clear whether better working conditions will lead to an improvement in export performance, or put another way, whether countries that tend to be characterized by lower labour standards do in fact have a competitive advantage in trade.

Table 2 shows the results when equation (20) is estimated using indicators other than conventions ratified. The results are quite similar to the ones obtained in Table 1, as only hour and leave are significant. The capital cost coefficient is of the expected sign but is not statistically significant. Once again, it is not clear whether export performance improves or deteriorates with higher labour standards since longer hours of work and more days of annual leave seem to both be a deterrent to export performance 
Table 2: Estimated coefficients for equation (20)- Developing Countries

\begin{tabular}{|c|c|c|c|c|c|c|}
\hline $\begin{array}{l}\text { Explanatory } \\
\text { Variables }\end{array}$ & (1) & (2) & (3) & (4) & (5) & (6) \\
\hline Constant & $\begin{array}{l}4.92 * * \\
(2.13)\end{array}$ & $\begin{array}{l}4.75 * * \\
(2.07)\end{array}$ & $\begin{array}{l}5.79 * \\
(1.77)\end{array}$ & $\begin{array}{c}0.30 \\
(0.83)\end{array}$ & $\begin{array}{l}-0.57^{*} \\
(-3.28)\end{array}$ & $\begin{array}{l}-0.66^{*} \\
(-1.77)\end{array}$ \\
\hline rint & $\begin{array}{c}-0.01 \\
(-0.70)\end{array}$ & $\begin{array}{c}-0.01 \\
(-0.89)\end{array}$ & $\begin{array}{c}-0.01 \\
(-0.46)\end{array}$ & $\begin{array}{c}-0.01 \\
(-0.44)\end{array}$ & $\begin{array}{l}-0.01 \\
(-0.70)\end{array}$ & $\begin{array}{c}-0.01 \\
(-0.55)\end{array}$ \\
\hline civilb & $\begin{array}{c}0.02 \\
(0.71)\end{array}$ & & & & & $\begin{array}{c}0.02 \\
(0.28)\end{array}$ \\
\hline $\log ($ hour $)$ & $\begin{array}{c}-1.32 * * \\
(-2.16)\end{array}$ & $\begin{array}{c}-1.26 * * \\
(-2.08)\end{array}$ & $\begin{array}{l}-1.44 * \\
(-1.69)\end{array}$ & & & \\
\hline $\log ($ leave $)$ & $\begin{array}{c}-0.23 * * \\
(-2.23)\end{array}$ & $\begin{array}{l}-0.22 * * \\
(-2.14)\end{array}$ & $\begin{array}{c}-0.35 * * \\
(-2.53)\end{array}$ & $\begin{array}{c}-0.36 * * \\
(-2.58)\end{array}$ & & \\
\hline union & & & $\begin{array}{c}-0.01 \\
(-0.15)\end{array}$ & $\begin{array}{c}-0.01 \\
(-0.10)\end{array}$ & & \\
\hline injuries & & & & & $\begin{array}{c}-0.48 \\
(-0.61)\end{array}$ & $\begin{array}{c}-0.48 \\
(-0.59)\end{array}$ \\
\hline $\mathrm{R}^{2}$ & 0.30 & 0.29 & 0.34 & 0.25 & 0.04 & 0.05 \\
\hline $\mathrm{N}$ & 39 & 39 & 28 & 28 & 19 & 19 \\
\hline F-Stat (p-value) & $2.87(0.03)$ & $3.51(0.02)$ & $2.91(0.04)$ & $2.72(0.07)$ & $1.82(0.20)$ & $1.32(0.32)$ \\
\hline White Test (p-value) & $0.98(0.50)$ & $0.92(0.52)$ & $1.46(0.25)$ & $0.42(0.91)$ & $0.97(0.48)$ & $0.55(0.80)$ \\
\hline \multicolumn{7}{|c|}{$\begin{array}{l}\text { Note: Except where indicated otherwise, the figures in parentheses are the t-values. }{ }^{*}(* *) \text { indicates } 10(5) \\
\text { percent level of significance. }\end{array}$} \\
\hline \multicolumn{7}{|c|}{ When developed countries are included in the regressions of Tables 1 and 2} \\
\hline labour standards $\mathrm{t}$ & end to becc & ome less si & ignificant. & When dev & veloped cou & intries are \\
\hline
\end{tabular}


highly significant. While this result might be an indication that the degree of unionization matters more for the export performance of developed countries than that of developing countries, it could also be due to an identification problem. Our results seem to indicate that labour standards exert a greater influence on the export performance of developing countries rather than developed countries.

\subsubsection{Labour Standards and Foreign Direct Investment}

An important feature of the world economy in the past two decades has been the phenomenal increase in foreign direct investment (FDI), or investment by transnational corporations or multinational enterprises in foreign countries. Since the early 1980s, world FDI flows have increased more rapidly than world trade or world output according to data from the International Monetary Fund (IMF). Equally striking is the fact that the developing countries' share in FDI inflows is also increasing, which means that the world market for FDI is becoming more competitive. Various competing explanations for the determinants of FDI can be found in the literature and while most of them have received some empirical support, it has been impossible to find enough favourable evidence on any one of them to discount all the others (see for example, De Jong and Vos (1994), Dunning (1977), Hymer (1976) and Lizondo (1990)).

We take a new stance by considering the influence of labour standards on FDI inflows across countries, and we consider FDI inflows for 1996 for the sample of countries taken from the OECD (1996) study and for which data is available. The decision to invest abroad in a particular country by any enterprise is motivated by the expectations of higher profits when ranked alongside alternative investment opportunities

(at home or other countries). Hence, the two explanatory variables included in the 
benchmark regressions are the gross national product (an indicator of market size) and the growth rate of gross domestic product (an indicator of future development potential). These two factors are found in many empirical studies related to FDI that tend to focus on economic factors. The model that we posit is essentially one that considers internal economic conditions in the host country as being important determinants of FDI. The equation that will be estimated is as follows:

$\log (F D I)_{t}=\alpha_{0}+\alpha_{1} \log \left(\right.$ gnp $_{t-1}+\alpha_{2}$ growth $_{t-1}+\alpha_{3}$ labstd $_{t-1}+\varepsilon_{t}$

where gnp refers to gross national product, growth refers to the growth rate of real gross domestic product, labstd is an indicator for labour standards (all included with a lag to be consistent with other studies) and $\varepsilon$ is the disturbance term. It is expected that the estimated coefficients $\alpha_{1}$ and $\alpha_{2}$ in the above equation will be positive. A higher gross national product and a high rate of growth are signs that an economy is doing well and that the future looks promising. Both are likely to have a positive influence on FDI.

As far as labour standards are concerned, the popular view suggests that FDI tends to flow to countries that are characterized by low labour standards. Hence, we want to check the hypothesis that low labour standards are attractive to foreign investors. The ordinary least squares estimates for a sample of non-OECD countries are reported in Table 3 below. The benchmark regression with the gross national product and the growth rate as explanatory variables is shown in the first column. The other columns show the results when different combinations of labour standards are tried. As expected, the sign of the coefficient for gnp is positive and is highly significant in regressions (1) to (6). On the other hand, the growth rate is not a very important factor that accounts for FDI inflows. 
The labour standard variables are all insignificant and the signs of the coefficients associated with civilb and union are contrary to the hypothesis that low labour standards are attractive to foreign investors. The coefficient on civilb in regression (3) is negative (that is, as civilb decreases, FDI increases) and this implies that high labour standards are attracting more FDI. The union variable has a positive coefficient (even though statistically insignificant) implying that a higher degree of unionization (better working conditions) attracts more FDI and this again contradicts the general belief on the relationship between FDI and labour standards. Equation (21) is also estimated for a sample that includes developed countries only (results not reported here). Overall, the results obtained are mixed. For instance, in the case of regression (4), the coefficients for gnp and growth are significant at 5\% and 10\% respectively, the coefficient on civilb is negative and significant at $10 \%$ for regression (4) and this implies that high labour standards are attracting more FDI. On the other hand, the union variable has a negative coefficient and is also significant at $10 \%$, implying that a higher degree of unionization (better working conditions) attracts less FDI. In sum, the above results reveal that there is no robust evidence that countries with low labour standards are attracting more FDI than those with high labour standards. 
Table 3: Foreign Direct Investment - Developing countries, 1996

\begin{tabular}{|c|c|c|c|c|c|c|}
\hline Explanatory Variables & (1) & (2) & (3) & (4) & $(5)$ & (6) \\
\hline Constant & $\begin{array}{c}-5.12 * * \\
(-5.45)\end{array}$ & $\begin{array}{c}-5.39 * * \\
(-3.77)\end{array}$ & $\begin{array}{c}5.63 \\
(0.51)\end{array}$ & $\begin{array}{c}-4.76^{* *} \\
(-3.00)\end{array}$ & $\begin{array}{l}-4.41 * \\
(-1.87)\end{array}$ & $\begin{array}{l}-4.41 * \\
(-1.83)\end{array}$ \\
\hline $\log (g n p)$ & $\begin{array}{l}1.09 * * \\
(10.88)\end{array}$ & $\begin{array}{l}1.11 * * \\
(8.12)\end{array}$ & $\begin{array}{c}1.08^{* *} \\
(9.29)\end{array}$ & $\begin{array}{l}1.03 * * \\
(6.79)\end{array}$ & $\begin{array}{l}1.00 * * \\
(3.16)\end{array}$ & $\begin{array}{c}0.95 * * \\
(3.13)\end{array}$ \\
\hline Growth & $\begin{array}{c}0.01 \\
(0.04)\end{array}$ & $\begin{array}{c}0.01 \\
(0.16)\end{array}$ & $\begin{array}{c}-0.01 \\
(-0.04)\end{array}$ & $\begin{array}{c}0.04 \\
(0.71)\end{array}$ & $\begin{array}{c}0.05 \\
(0.50)\end{array}$ & $\begin{array}{c}0.06 \\
(0.56)\end{array}$ \\
\hline cconv & & $\begin{array}{c}-0.05 \\
(-0.33)\end{array}$ & & & & \\
\hline tconv & & $\begin{array}{c}0.01 \\
(0.58)\end{array}$ & & & & \\
\hline civilb & & & $\begin{array}{c}-0.17 \\
(-1.19)\end{array}$ & $\begin{array}{c}-0.05 \\
(-0.33)\end{array}$ & & $\begin{array}{c}0.12 \\
(0.44)\end{array}$ \\
\hline $\log ($ hour $)$ & & & $\begin{array}{c}-2.53 \\
(-0.86)\end{array}$ & & & \\
\hline $\log ($ leave $)$ & & & $\begin{array}{c}-0.09 \\
(-0.20)\end{array}$ & & & \\
\hline union & & & & $\begin{array}{c}0.03 \\
(1.22)\end{array}$ & & \\
\hline injuries & & & & & $\begin{array}{c}0.11 \\
(0.03)\end{array}$ & $\begin{array}{c}0.44 \\
(0.12)\end{array}$ \\
\hline $\mathrm{R}^{2}$ & 0.77 & 0.73 & 0.74 & 0.73 & 0.66 & 0.66 \\
\hline $\mathrm{N}$ & 46 & 41 & 43 & 30 & 21 & 21 \\
\hline F-Stat (p-value) & $\begin{array}{l}71.78 \\
(0.00)\end{array}$ & $\begin{array}{l}24.47 \\
(0.00)\end{array}$ & $\begin{array}{l}20.94 \\
(0.00)\end{array}$ & $\begin{array}{l}16.92 \\
(0.00)\end{array}$ & $\begin{array}{l}10.85 \\
(0.00)\end{array}$ & $\begin{array}{c}7.81 \\
(0.00)\end{array}$ \\
\hline White Test (p-value) & $\begin{array}{c}1.21 \\
(0.32)\end{array}$ & $\begin{array}{c}0.42 \\
(0.95)\end{array}$ & $\begin{array}{c}0.49 \\
(0.94)\end{array}$ & $\begin{array}{c}0.43 \\
(0.94)\end{array}$ & $\begin{array}{c}0.24 \\
(0.98)\end{array}$ & $\begin{array}{c}0.20 \\
(0.99)\end{array}$ \\
\hline
\end{tabular}

$\overline{\text { Note: Except where indicated otherwise, the figures in parentheses are the t-values. }{ }^{*}\left({ }^{* *}\right) \text { indicates } 10(5)}$ percent level of significance. 


\section{$4 \quad$ New Empirical Evidence - Time Series Analysis}

In this section, we consider the empirical effects of different measures of labour standards on the behaviour of exports for Canada using annual data for the period 1950 to1998. ${ }^{6}$ We use the perfect and imperfect substitutes models outlined in the previous section but in a time series framework. However, as far as indicators for labour standards are concerned, we do not consider conventions ratified at all when we examine the stationarity properties of the different time series for Canada since they are not continuous variables. Unlike the general approach in the literature, which is based on cross-sectional analysis, we therefore use a time series approach. This approach is useful since we consider long-term time series data, which means that there is always the possibility that a structural change (an exogenous shock) could have occurred. In the case of the United States (see Rodriguez and Samy (2001)), this approach allows the identification of breaks in the data so that one is able to consider the effects of labour standards under different regimes. In our future research on this subject, we are planning to extend our analysis to a full-fledged panel data approach, which would allow for the richness of both time series and cross-sectional variation in the data. For now, given data considerations, we consider the two approaches separately.

In the case of Canada, the ADF tests presented evidence of non-stationarity and except for the variable related to occupational injuries, the others were difference stationary. We therefore estimate a vector autoregressive model and we also provide estimates for the error correction model. Results for the estimation of a $\operatorname{VAR}(1)$ for Canada are presented in Table 4 below and the lag was chosen using the AIC criterion.

\footnotetext{
${ }^{6}$ For results pertaining to the United States, please refer to Rodriguez and Samy (2001).
} 
Table 4: Estimated coefficients for equation (19), Canada, 1950-1998: VAR(1)

\begin{tabular}{|c|c|c|c|c|c|c|}
\hline $\begin{array}{l}\text { Explanatory } \\
\text { Variables }\end{array}$ & (1) & (2) & (3) & (4) & (5) & (6) \\
\hline Constant & $\begin{array}{c}-0.01 \\
(-0.86)\end{array}$ & $\begin{array}{c}-0.04 \\
(-1.51)\end{array}$ & $\begin{array}{c}0.05 * * \\
(2.52)\end{array}$ & $\begin{array}{l}0.01 * \\
(1.72)\end{array}$ & $\begin{array}{c}0.01 \\
(1.07)\end{array}$ & $\begin{array}{c}0.05 * * \\
(2.42)\end{array}$ \\
\hline$\Delta \log (\exp / g d p)_{t}(-1)$ & $\begin{array}{c}0.20 \\
(1.34)\end{array}$ & $\begin{array}{c}0.19 \\
(1.25)\end{array}$ & $\begin{array}{c}0.23 \\
(1.67)\end{array}$ & $\begin{array}{c}0.22 \\
(1.59)\end{array}$ & $\begin{array}{c}0.30 * * \\
(2.08)\end{array}$ & $\begin{array}{c}0.20 \\
(1.50)\end{array}$ \\
\hline $\operatorname{cconv}_{t}(-1)$ & $\begin{array}{c}0.01 \\
(1.65)\end{array}$ & & & & & \\
\hline $\operatorname{tconv}_{t}(-1)$ & & $\begin{array}{l}0.01 * \\
(1.71)\end{array}$ & & & & \\
\hline $\operatorname{inj}_{t}(-1)$ & & & $\begin{array}{c}-0.35 * * \\
(-2.41)\end{array}$ & & & $\begin{array}{c}-0.32 * * \\
(-2.27)\end{array}$ \\
\hline$\Delta$ lhour $_{t}(-1)$ & & & & $\begin{array}{c}0.90 * * \\
(2.34)\end{array}$ & & $\begin{array}{c}0.79 * * \\
(2.11)\end{array}$ \\
\hline$d t c_{t}$ & & & $\begin{array}{c}-0.02 \\
(-1.60)\end{array}$ & & & $\begin{array}{c}-0.01 \\
(-1.41)\end{array}$ \\
\hline $\operatorname{sunion}_{t}(-1)$ & & & & & $\begin{array}{c}0.01 \\
(1.23)\end{array}$ & $\begin{array}{c}0.01 \\
(1.62)\end{array}$ \\
\hline $\mathrm{R}^{2}$ & 0.14 & 0.14 & 0.20 & 0.18 & 0.11 & 0.32 \\
\hline $\begin{array}{l}\mathrm{N} \\
\text { AIC }\end{array}$ & $\begin{array}{c}46 \\
-4.53\end{array}$ & $\begin{array}{c}46 \\
-3.05\end{array}$ & $\begin{array}{c}46 \\
-9.60\end{array}$ & $\begin{array}{c}46 \\
-11.12\end{array}$ & $\begin{array}{c}46 \\
-1.83\end{array}$ & $\begin{array}{c}46 \\
-13.34\end{array}$ \\
\hline $\mathrm{SIC}$ & -4.30 & -2.81 & -9.28 & -10.88 & -1.59 & -12.38 \\
\hline
\end{tabular}

When the variable inj $_{t}$ is included in the regressions, a dummy $(d t c)$ for a break in the intercept is considered. Overall, the results indicate that $i_{n j}$ and $\Delta$ lhour $_{t}$ are significant while the rate of unionization is not a significant factor. Total ILO Conventions ratified $\left(\operatorname{tconv}_{t}\right)$ is also significant at the $10 \%$ level. However, the signs of 
tconv $v_{t}$ and $i n j_{t}$ indicate that higher labour standards have led to an improvement in export performance. In the case of $\Delta l$ hour , higher labour standards have had the opposite effect on export performance. Hence, only the latter labour standard is consistent with the view that low labour standards provide a competitive advantage in trade and lead to an improvement in export performance in the case of Canada.

Table 5: Cointegration and error correction model, equation (20), Canada:

\begin{tabular}{ccccc}
\hline \hline \multicolumn{4}{c}{ Cointegrating Equation } \\
$\log (\exp / g d p)_{t}(-1)$ & injt $(-1)$ & hhour $_{t}(-1)$ & union $_{t}(-1)$ & Constant \\
1.00 & -6.41 & $16.26^{*}$ & 0.07 & -60.67 \\
& $(-1.41)$ & $(1.87)$ & $(1.45)$ & \\
\hline \hline & & & \\
\hline
\end{tabular}

Error Correction Term: $-0.03 *(-1.68)$

$\begin{array}{ccccc}\Delta \log \left(\exp / \text { gdp }_{t}(-1)\right. & \text { inj }_{t}(-1) & \Delta \text { hour }_{t}(-1) & \Delta \text { union }_{t}(-1) & \text { Constant } \\ 0.33^{* *} & -0.39^{* *} & 1.31^{* *} & 0.01 & 0.01 \\ (2.41) & (-2.17) & (2.98) & (1.08) & (1.36) \\ & & & & \\ \mathrm{R}^{2} & 0.32 & & & \\ \mathrm{~N} & 46 & & & \end{array}$

Note: Except where indicated otherwise, the figures in parentheses are the t-values. ${ }^{*}(* *)$ indicates $10(5)$ percent level of significance.

Finally, the set of VAR(1) estimates can be improved using the cointegration framework. In fact, given the results of the stationarity analysis, cointegration is a possibility among the set of variables considered. Using the Johansen test, we find evidence (at 5\% level of significance) in favour of one cointegrating vector. The results are presented in Table 5 above. The top panel of the table shows the estimate of the cointegration relation. The bottom panel shows the estimate for the error correction for the dependent variable. The coefficient associated to the long-term equation is significant with the correct sign. In this specification, all the explanatory variables are significant 
except the variable union $_{t}(-1)$. Past export performance is a significant factor in explaining present export performance. As far as the signs of the labour standards variables are concerned, only $\Delta l$ hour $t_{t}$ is consistent with the view that low labour standards lead to higher export performance. The rate of injuries has the opposite effect.

\section{$5 \quad$ Policy Implications}

In this paper we have considered what theory and empirics has to say on the question of the effect of labour standards on international trade. Contrary to the popular notions that animate much of the distrust of the global trading system amongst certain segments of the NGO community, there is no clearcut link, either in theory or practice, between the level of stringency of labour standards and a country's "competitiveness", whether measured by its terms of trade (in the theoretical model) or the extent to which it attracts FDI (in the empirical work). ${ }^{7}$ Standards are, of course, important and may affect trade and investment flows as documented in our research, but there is, in general, no basis for the fear that increased trade or FDI flows amongst countries of different standards levels will induce a "race to the bottom" in which all are left worse off. ${ }^{8}$ To see that this is not a straw man that we have created, consider the slogan of the Canadian Auto Workers $(\mathrm{CAW})$ at their recent meeting when deciding strategy on negotiating with the US auto makers: "No rules. No borders. No jobs": the clear implication being that unrestricted trade between Canada and the US would put pressure on Canadian labour markets and/or standards. It may be a useful notion for labour unions to put forward when negotiating, but it is not, in general, supported by the evidence.

\footnotetext{
${ }^{7}$ Our "benign" conclusions are also echoed in recent work on the related issue of child labour, Cigno, Rosati, and Guarcello (2002).
} 
Our research points to the need for great caution when making policy pronouncements on the linkages between trade and labour standards. But we do not wish to end on a pessimistic note, by rather by reiterating the essential wisdom of the fundamental trade-theoretic insight which illuminates this nexus: namely, labour standards are ultimately a matter of domestic policy choice, and comparative advantage is enhanced by diversity of standards, not by an artificial harmonization or "straitjacketing" of countries into a particular country's favoured standard.

\footnotetext{
${ }^{8}$ This message is reinforced in the context of an alternative theoretical model, Sinn (2003).
} 
Appendix A

\section{Country List}

Argentina
Australia
Austria
Bahamas, The
Bangladesh
Barbados
Belgium
Bolivia
Botswana
Canada
Chile
China
Colombia
Denmark
Ecuador
Egypt
Ethiopia
Fiji
Finland
France
Germany
Greece
Guatemala
Haiti

Honduras

Hong Kong

Iceland

India

Indonesia

Ireland

Israel

Italy

Jamaica

Japan

Jordan

Kenya

Korea, Rep.

Kuwait

Luxembourg

Malaysia

Malta

Mauritius

Mexico

Morocco

Netherlands

New Zealand

Niger

Norway
Pakistan

Panama

Papua New Guinea

Peru

Philippines

Portugal

Singapore

South Africa

Spain

Sri Lanka

Suriname

Swaziland

Sweden

Switzerland

Syrian Arab Republic

Tanzania

Thailand

Turkey

United Kingdom

United States

Uruguay

Venezuela

Zambia

Zimbabwe 


\title{
Data Sources
}

Appendix B

\author{
Variables \\ Sources \\ $\exp$ \\ International Financial Statistics Yearbook 1999 (Washington \\ D.C: IMF, 1999) \\ $g d p$ \\ Global Development Finance and World Indicators \\ Lending rate \\ International Financial Statistics Yearbook 1999 (Washington \\ D.C: IMF, 1999) \\ Rate of inflation \\ World Economic Outlook October 1999 (Washington D.C: \\ IMF, 1999) \\ tconv \\ World Employment Report 1995 \\ hour, leave \\ Conditions of Work Digest: Working Time around The World \\ (Geneva: International Labour Office, 1995) \\ civilb \\ Freedom in the World: The Annual Survey of Political Rights \\ and Civil Liberties 1994-1995 (New York: Freedom House, \\ 1995) \\ union \\ World Labour Report 1997-98: Industrial Relations, Democracy \\ and Social Stability (Geneva, International Labour Office,1997) \\ injuries \\ LABORSTA - ILO Database \\ $f d i$ \\ World Investment Report 1999: FDI and the Challenge of \\ Development (New York and Geneva, United Nations, 1999) \\ gnp \\ World Development Report 1997 (Washington D.C: World \\ Bank, 1997) \\ growth \\ World Development Report 1997 (Washington D.C: World \\ Bank, 1997)
}




\section{References}

Alam, A. (1992), “Labour Standards and Comparative Advantage,” Unpublished Doctoral Dissertation, Columbia University.

Bai, J. and P. Perron (1998a), "Computation and Analysis of Multiple StructuralChange Models," Econometrica, 66, 47-78.

Bai, J. and P. Perron. (1998b), "Computation and Analysis of Multiple StructuralChange Models," Université de Montreal, CRDE, Cahier 0998.

Bhagwati, J.N. and R.E. Hudec (1996), Fair Trade and Harmonization: Prerequisites for Free Trade?, MIT, Cambridge, Massachusetts.

Bhagwati, J.N. and T.N. Srinivasan (1994), Lectures on International Trade, MIT, Cambridge, Massachusetts.

Brecher, R.A. (1974a), “Optimal Commercial Policy for a Minimum-Wage Economy,” Journal of International Economics, 4, 139-49.

Brecher, R.A. (1974b), "Minimum Wage Rates and the Pure Theory of International Trade," Quarterly Journal of Economics, 88, 98-116.

Brown, D.K., Deardoff, A.V. and R.M. Stern (1996), “International Labour Standards and Trade: A Theoretical Analysis," in Fair Trade and Harmonization: Prerequisites for Free Trade? Volume 1, edited by J.N. Bhagwati and R.E. Hudec, MIT, Cambridge, Massachusetts.

Cigno, A., Rosati, F.C., and L. Guarcello (2002), “Does Globalisation Increase Child Labour?", CESifo conference paper, November 8-9 2002, CESifo, Munich, Germany.

Dehejia, V.H. and L. Garbo (1994), “Standards Harmonization, Comparative Advantage and Growth: The General Equilibrium Implications of Ross Perot," Unpublished Paper, Columbia University.

Dehejia, V.H. (1998). “Can Standards Immiserize?”, Economics Letters, 59, 361-66.

De Jong, N. and R. Vos (1994), “Theoretical and Empirical Approaches to Direct Foreign Investment: A survey of the literature," Institute of Social Studies, The Hague.

Dunning, J.H. (1977), "Trade, Location of Economic Activity and the MNE: A Search for an Eclectic Approach," in The International Allocation of Economic Activity, edited by B. Ohlin, P.O. Hesselborn, and P.J. Wiskman, Macmillan, London. 
Freedom House (1995), Freedom in the World: The Annual Survey of Political Rights and Civil Liberties 1994-1995, New York.

Goldstein, M. and M.S. Khan (1985), "Income and Price Effects in Foreign Trade", in Handbook of International Economics, Vol. 2, edited by R.W. Jones and P.B. Kenen, North-Holland, Amsterdam.

Hymer, S.H. (1976), The International Operations of National Firms: A Study of Direct Foreign Investment, MIT Press, Cambridge, MA.

ILO (1995), Conditions of Work Digest: Working Time Around The World, International Labour Office, Geneva.

ILO (1995), World Labour Report 1995, International Labour Office, Geneva.

ILO (1997), World Labour Report 1997-98: Industrial Relations, Democracy and Social Stability, International Labour Office, Geneva.

IMF (1999), International Financial Statistics Yearbook 1999, International Monetary Fund, Washington D.C.

IMF (1999), World Economic Outlook October 1999, International Monetary Fund, Washington D.C.

Johnson, H.G. (1969), "Minimum Wage Laws: A General Equilibrium Analysis," Canadian Journal of Economics, 2, 599-604.

Komiya, R. (1967), "Non-traded Goods and the Pure Theory of International Trade," International Economic Review, 8, 132-152.

Krueger, A.B. (2000), "From Bismarck to Maastricht: The March to European Union and the Labour Compact," NBER Working Paper No. 7456, January.

Lizondo, S.J. (1990), “Foreign Direct Investment,” IMF Working Paper.

Mah, J.S. (1997), "Core Labour Standards and Export Performance in Developing Countries," The World Economy 20(6).

OECD (1996), Trade, Employment and Labour Standards, Organization for Economic Cooperation and Development, Paris, France.

Rodrik, D. (1996), "Labour Standards in International Trade: Do they matter and what do we do about them?" in Emerging agenda for global trade: High stakes for developing countries, Overseas Development Council, Washington D.C. 
Rodriguez, G. and Y. Samy (2001), “Analyzing the Effects of Labour Standards on U.S. Export Performance. A Time Series Approach with Structural Change," Working Paper 0108E, Department of Economics, University of Ottawa (forthcoming: Applied Economics)

Sinn, H.-W. (2003). The New Systems Competition. Blackwell Publishing, Oxford, UK (forthcoming).

United Nations (1999), World Investment Report 1999: FDI and the Challenge of Development, United Nations, New York and Geneva.

World Bank (2000), Global Development Finance 2000, World Bank, Washington D.C. 


\section{CESifo Working Paper Series}

(for full list see www.cesifo.de)

765 Giovanni Peri, Knowledge Flows and Knowledge Externalities, August 2002

766 Daniel Friedman and Nirvikar Singh, Equilibrium Vengeance, August 2002

767 Sam Bucovetsky and Michael Smart, The Efficiency Consequences of Local Revenue Equalization: Tax Competition and Tax Distortions, August 2002

768 Tapio Palokangas, International Labour Market Regulation and Economic Growth with Creative Destruction, August 2002

769 Rudi Dornbusch, The New International Architecture, September 2002

770 Hans-Werner Sinn, Weber's Law and the Biological Evolution of Risk Preferences: The Selective Dominance of the Logarithmic Utility Function, September 2002

771 Thomas Mayer, The Macroeconomic Loss Function: A Critical Note, September 2002

772 Seppo Honkapohja and Kaushik Mitra, Learning Stability in Economies with Heterogenous Agents, September 2002

773 David Laidler, Inflation Targets Versus International Monetary Integration - A Canadian Perspective, September 2002

774 Morten I. Lau, Panu Poutvaara, and Andreas Wagener, The Dynamic Cost of the Draft, September 2002

775 Steven Brakman, Harry Garretsen, and Charles van Marrewijk, Locational Competition and Agglomeration: The Role of Government Spending, September 2002

776 Anke S. Kessler and Christoph Lülfesmann, The Theory of Human Capital Revisited: On the Interaction of General and Specific Investments, September 2002

777 Kjell Erik Lommerud, Frode Meland and Lars Sørgard, Unionized Oligopoly, Trade Liberalization and Location Choice, September 2002

778 Antonio Merlo and François Ortalo-Magné, Bargaining over Residential Real Estate: Evidence from England, September 2002

$779 \mathrm{Yu}-\mathrm{Fu}$ Chen and Michael Funke, Exchange Rate Uncertainty and Labour Market Adjustment under Fixed and Flexible Exchange Rates, September 2002

780 Michael S. Michael, International Migration, Income Taxes and Transfers: A Welfare Analysis, September 2002 
781 Clemens Fuest and Alfons Weichenrieder, Tax Competition and Profit Shifting: On the Relationship between Personal and Corporate Tax Rates, October 2002

782 Jan Bouckaert and Hans Degryse, Softening Competition by Enhancing Entry: An Example from the Banking Industry, October 2002

783 Johann K. Brunner and Susanne Pech, Adverse Selection in the Annuity Market with Sequential and Simultaneous Insurance Demand, October 2002

784 Gregory D. Hess and Eduard Pelz, The Economic Welfare Cost of Conflict: An Empirical Assessment, October 2002

785 Jan Erik Askildsen, Uwe Jirjahn, and Stephen C. Smith, Works Councils and Environmental Investment: Theory and Evidence from German Panel Data, October 2002

786 Geir H. Bjønnes, Dagfinn Rime, and Haakon O. Aa. Solheim, Volume and Volatility in the FX-Market: Does it matter who you are?, October 2002

787 John Evans and John Fingleton, Entry Regulation and the Influence of an Incumbent Special Interest Group, October 2002

788 Wolfgang Ochel, International Comparisons and Transfer of Labour Market Institutions, October 2002

789 B. Gabriela Mundaca, Moral Hazard Effects of Bailing out under Asymmetric Information, October 2002

790 Gene M. Grossman and Edwin L.-C. Lai, International Protection of Intellectual Property, October 2002

791 John Hassler, José V. Rodriguez Mora, Kjetil Storesletten, and Fabrizio Zilibotti, A Positive Theory of Geographic Mobility and Social Insurance, October 2002

792 Paul De Grauwe and Marianna Grimaldi, The Exchange Rate in a Model with Heterogeneous Agents and Transactions Costs, October 2002

793 Guido Friebel and Mariassunta Giannetti, Fighting for Talent: Risk-shifting, Corporate Volatility, and Organizational Change, October 2002

794 Jan Erik Askildsen, Badi H. Baltagi, and Tor Helge Holmås, Will Increased Wages Reduce Shortage of Nurses? A Panel Data Analysis of Nurses' Labour Supply, October 2002

795 Marko Köthenbürger and Panu Poutvaara, Social Security Reform and Intergenerational Trade: Is there Scope for a Pareto-Improvement?, October 2002

796 Paul De Grauwe and Laura Rinaldi, A Model of the Card Payment System and the Interchange Fee, October 2002 
797 Volker Böhm and Tomoo Kikuchi, Dynamics of Endogenous Business Cycles and Exchange Rate Volatility, October 2002

798 Mariam Camarero, Javier Ordóñez, and Cecilio Tamarit, The Euro-Dollar Exchange Rate: Is it Fundamental?, October 2002

799 Misa Tanaka, How Do Bank Capital and Capital Adequacy Regulation Affect the Monetary Transmission Mechanism?, October 2002

800 Jörg Baten and Andrea Wagner, Autarchy, Market Disintegration, and Health: The Mortality and Nutritional Crisis in Nazi Germany, 1933-1937, October 2002

801 Saku Aura, Uncommitted Couples: Some Efficiency and Policy Implications of Marital Bargaining, October 2002

802 Wolfram F. Richter, Delaying Integration of Immigrant Labor for the Purpose of Taxation, October 2002

803 Gil S. Epstein and Shmuel Nitzan, The Politics of Randomness, October 2002

804 John Hassler and José V. Rodriguez Mora, Should UI Benefits Really Fall over Time?, October 2002

805 Friedrich Breyer and Stefan Felder, The Dead-anyway Effect Revis(it)ed, October 2002

806 Assar Lindbeck and Solveig Wikström, E-exchange and the Boundary between Households and Organizations, November 2002

807 Dieter Bös, Contests Among Bureaucrats, November 2002

808 Steven Brakman, Harry Garretsen, and Marc Schramm, The Strategic Bombing of German Cities during World War II and its Impact on City Growth, November 2002

809 Florian Englmaier and Achim Wambach, Contracts and Inequity Aversion, November 2002

810 Sarbajit Sengupta, Delegating Recruitment under Asymmetric Information, December 2002

811 Rajshri Jayaraman, On the Partial Public Provision of a Private Good, December 2002

812 Stéphanie Stolz, Banking Supervision in Integrated Financial Markets: Implications for the EU, December 2002

813 Christian Keuschnigg, Taxation of a Venture Capitalist with a Portfolio of Firms, December 2002

814 Inés Macho-Stadler and David Pérez-Castrillo, Settlement in Tax Evasion Prosecution, December 2002 
815 Rainer Niemann and Dirk Simons, Costs, Benefits, and Tax-induced Distortions of Stock Option Plans, December 2002

816 Jan-Egbert Sturm and Barry Williams, Deregulation, Entry of Foreign Banks and Bank Efficiency in Australia, December 2002

817 V. Anton Muscatelli, Patrizio Tirelli, and Carmine Trecroci, Monetary and Fiscal Policy Interactions over the Cycle: Some Empirical Evidence, December 2002

818 Claude Hillinger, A General Theory of Price and Quantity Aggregation and Welfare Measurement, December 2002

819 Erkki Koskela and Ronnie Schöb, Optimal Capital Taxation in Economies with Unionised and Competitive Labour Markets, December 2002

820 Sheilagh Ogilvie, Guilds, Efficiency, and Social Capital: Evidence from German ProtoIndustry, December 2002

821 Hans Gersbach and Verena Liessem, Financing Democracy, December 2002

822 Costas Hadjiyiannis, Panos Hatzipanayotou, and Michael S. Michael, Optimal Tax Policies with Private-Public Clean-Up, Cross-Border Pollution and Capital Mobility, December 2002

823 François Ortalo-Magné and Sven Rady, Homeownership: Low Household Mobility, Volatile Housing Prices, High Income Dispersion, December 2002

824 Syed M. Ahsan and Panagiotis Tsigaris, Measuring the Social Discount Rate under Uncertainty: A Methodology and Application, December 2002

825 Kai A. Konrad, Altruism and Envy in Contests: An Evolutionarily Stable Symbiosis, December 2002

826 Robert S. Chirinko and Huntley Schaller, A Revealed Preference Approach to Understanding Corporate Governance Problems: Evidence from Canada, December 2002

827 Geir B. Asheim, Green National Accounting for Welfare and Sustainability: A Taxonomy of Assumptions and Results, December 2002

828 Andrea Gebauer, Chang Woon Nam, and Rüdiger Parsche, Lessons of the 1999 Abolition of Intra-EU Duty Free Sales for Eastern European EU Candidates, December 2002

829 Giacomo Corneo, Work and Television, December 2002

830 Vivek H. Dehejia and Yiagadeesen Samy, Trade and Labour Standards - Theory, New Empirical Evidence, and Policy Implications, December 2002 